\title{
Multivariate Optimization of Microwave-Assisted Digestion of Copper and Zinc from Powder Milk
}

\author{
Mostafa Khajeh* \\ Department of Chemistry, University of Zabol, P. O. Box 98615-538, Zabol, Iran
}

\begin{abstract}
Neste trabalho, um método fácil e rápido de digestão assistida por micro-ondas combinado com espectrometria de absorção atômica por chama (FAAS) foi desenvolvido para determinações de zinco e cobre em amostras de leite. A potência da irradiação, o volume de ácido nítrico, a temperatura e o tempo de digestão foram selecionados para a otimização deste trabalho. Os resultados do planejamento fatorial completo de 2 níveis $\left(2^{4}\right)$ baseado em análise de variância (ANOVA) e diagrama de Pareto mostraram que todos os fatores são estatisticamente significantes. As condições ideais das extrações dos analitos em amostras de leite foram obtidas por metodologia de superfície de resposta (RSM) baseada no planejamento experimental Box-Behnken. Uma condição de compromisso entre as melhores condições para cada analito foi selecionada para a aplicação do método proposto, na determinação de zinco e cobre em amostras de leite. Estes valores foram $110^{\circ} \mathrm{C}, 450 \mathrm{~W}, 4,0 \mathrm{~mL}$ e $21,0 \mathrm{~min}$, para temperatura, potência da irradiação, volume de ácido nítrico e tempo de digestão, respectivamente.
\end{abstract}

In the present study, an easy and fast microwave-assisted digestion method combined with flame atomic absorption spectrometry (FAAS) was developed for zinc and copper determinations in milk samples. The irradiation power, volume of nitric acid, temperature and digestion time were selected for optimization in this work study. The results of 2-level full factorial $\left(2^{4}\right)$ design based on analysis of variance (ANOVA) and Pareto chart showed that all of factors were statistically significant. The optimal conditions for the analytes extraction in milk samples were obtained by response surface methodology (RSM) based on Box-Behnken experimental design. The conditions of work were accepted as an agreement between optimal values that were found for the analytes. These values were $110^{\circ} \mathrm{C}, 450 \mathrm{~W}, 4.0 \mathrm{~mL}$ and $21.0 \mathrm{~min}$ for temperature, irradiation power, volume of nitric acid and digestion time, respectively. This procedure was applied to the zinc and copper determinations in milk samples.

Keywords: zinc, copper, Box-Behnken design, microwave-assisted digestion, milk samples

\section{Introduction}

Milk provides all macronutrients (such as carbohydrates, lipids and proteins) and all micronutrients. Therefore, it is known as an almost complete nutritional product in the human diet. ${ }^{1}$ This is especially true in the case of early childhood since milk is a unique food source in the first months of life of the baby and the growing children diet containing a high proportion of milk and dairy products. A sufficient intake of milk is also recommended for adults whereas calcium source for maintaining mass of the bone to prevent fractures and osteoporosis. ${ }^{1,2}$ It is need to develop the exact analytical methods for analysis of zinc and copper in the milk samples for the quality control.

*e-mail: m_khajeh@uoz.ac.ir
Copper is categorized as an essential element due to the fact that its deficiency affects iron metabolism in human infants, resulting in various clinical syndromes. ${ }^{3}$ The infant milk intake normally fulfils this requirement, but the presence of a high copper concentration is toxic and causes acrodynia. Zinc is an integral part of enzymes such as carbonic anhydrase and alkaline phosphatase. Dairy products are reported to contribute up to $5 \%$ of the daily intake and hypogonadism and dwarfism resulting from its deficiency have been reported in the literature. ${ }^{3}$ Multielement control of micro- and macro-contaminants and/ or constituents in complex matrices, such as milk, usually requires sample clean-up. This represents an important stage in analysis because it must be able to disaggregate the fat and protein matrix with minimum reagent addition. One of the most common procedures involves 
precipitation of the milk proteins with trichloroacetic acid, ${ }^{4}$ dry ashing ${ }^{5}$ and wet digestion ${ }^{6}$ are also currently used. The preference for microwave radiation over other digestion methods for biological samples is evident in the literature. ${ }^{7}$ The sequence analysis time can be reduced by using a microwave oven, thus leading to greater in analytical sampling rate. ${ }^{8}$

The response surface methodology (RSM) is a good tool for determining experimental factor settings ${ }^{9}$ and assesses the relationship between experimental and observed results..$^{10}$ It is a mathematical tool that can aid to find the optimum conditions for a reaction with the minimum number of experiments to obtain statistically acceptable results. ${ }^{11}$ The Box-Behnken is an experimental design that have also been used by other researchers for optimization studies. ${ }^{12-14}$

In this work, the microwave-assisted digestion system was used for the extraction of zinc and copper from milk samples and their determination by flame atomic absorption spectrometry (FAAS). The optimization of the irradiation power, digestion time, volume of nitric acid and temperature is described using a Box-Behnken matrix.

\section{Experimental}

\section{Apparatus}

The measurements were performed with a Konik Won M300 (Barcelona, Spain) flame atomic absorption spectrometer equipped with a conventional pneumatic nebulizer, and nebulization chamber was used for the analysis. Hollow cathode lamp for determination of copper and zinc was used. The most sensitive wavelengths for copper at $324.8 \mathrm{~nm}$ and for zinc at $213.9 \mathrm{~nm}$ were used with bandwidths of 1.2 and $0.5 \mathrm{~nm}$ for copper and zinc, respectively. The flame composition was acetylene (flow rate of $1.5 \mathrm{~L} \mathrm{~min}^{-1}$ ) and air (flow rate of $10.0 \mathrm{~L} \mathrm{~min}^{-1}$ ), and the burner height was set to $8 \mathrm{~mm}$. The nebulizer flow rate aspiration was kept between 5.0 and $5.5 \mathrm{~mL} \mathrm{~min}^{-1}$. The microwave digestion was carried out by an Ethos SEL apparatus (Milestone, Sorisole, Italy).

\section{Materials}

Nitric acid used was of the highest purity available from Merck (Darmstadt, Germany). Reagent grades of salts (all from Merck) were of the highest purity available. A stock standard solution containing $1000 \mathrm{mg} \mathrm{L}^{-1}$ of each element was used in preparing calibration standards. The calibration solutions were prepared from stock solution using deionized water immediately before analysis. The powder milk samples were purchased from local market in Iran.

\section{Microwave-assisted procedure}

The microwave-assisted digestion technique was adopted for the mineralization of the milk samples after some preliminary experiments. This method uses less reagent volumes and shorter digestion time. ${ }^{1}$ Milk powder sample aliquot $(0.5 \mathrm{~g})$ was weighed and then transferred to a closed-vessel. Then, appropriate amount of nitric acid was added. According to a preliminary Box-Behnken experimental matrix, the digestions of samples were carried out at different conditions: digestion time from 16 to $30 \mathrm{~min}$, volume of nitric acid from 2 to $6 \mathrm{~mL}$, temperature ranging from 80 to $120^{\circ} \mathrm{C}$ and irradiation power from 300 to $500 \mathrm{~W}$. The resulted solution was transferred to $10 \mathrm{~mL}$ volumetric flask and brought up to the mark with doubly distilled water. The concentrations of zinc and copper in the solutions were determined by FAAS. The procedure was performed in triplicate.

\section{Statistical analysis}

The data were analyzed by the Pareto chart and the analysis of variance (ANOVA) was applied to examine the statistical significance of factors. A level of the probability of 0.05 was considered statistically significant. The Box-Behnken experimental design was used for final optimization. The MiniTab 14 software was applied for statistical analysis.

\section{Factorial design}

The factors chosen considering the microwave-assisted digestion system were: power (100-200 W), volume of nitric acid (4-8 $\mathrm{mL}$ ), time (5-15 $\mathrm{min}$ ) and temperature (60$\left.80^{\circ} \mathrm{C}\right)$. A two-level full factorial design $\left(2^{4}\right)$ was performed in triplicate to determine the effect of each variable and its interactions in the procedure of extraction. Table 1 shows the experimental design and results derived from each run. ANOVA was used to investigate the significant of the effects. The Pareto chart (Figure 1) also shows the statistically significant factors. In the interpretation of this chart, it should be noted that the lengths of the bar are proportional to the absolute value of the estimated effects. A bar crossing this vertical line corresponds to a factor or a combination of factors that have a significant influence on response. This chart demonstrates that all of the factors were significant. 
Table 1. Experimental design of the results obtained in function of the $\mu \mathrm{g} \mathrm{g}^{-1}$ of zinc

\begin{tabular}{|c|c|c|c|c|c|}
\hline Trial No. & Power / W & Temperature $/{ }^{\circ} \mathrm{C}$ & time / min & Volume / mL & Amount / $(\mu \mathrm{g}$ per $0.5 \mathrm{~g})$ \\
\hline 1 & 100 & 60 & 5 & 4 & 66.86 \\
\hline 2 & 300 & 60 & 5 & 4 & 68.38 \\
\hline 3 & 100 & 80 & 5 & 4 & 62.98 \\
\hline 4 & 300 & 80 & 5 & 4 & 66.52 \\
\hline 5 & 100 & 60 & 15 & 4 & 59.30 \\
\hline 6 & 300 & 60 & 15 & 4 & 65.37 \\
\hline 7 & 100 & 80 & 15 & 4 & 63.54 \\
\hline 8 & 300 & 80 & 15 & 4 & 75.04 \\
\hline 9 & 100 & 60 & 5 & 8 & 53.15 \\
\hline 10 & 300 & 60 & 5 & 8 & 58.32 \\
\hline 11 & 100 & 80 & 5 & 8 & 54.19 \\
\hline 12 & 300 & 80 & 5 & 8 & 67.03 \\
\hline 13 & 100 & 60 & 15 & 8 & 47.20 \\
\hline 14 & 300 & 60 & 15 & 8 & 58.64 \\
\hline 15 & 100 & 80 & 15 & 8 & 54.49 \\
\hline 16 & 300 & 80 & 15 & 8 & 79.25 \\
\hline 17 & 200 & 70 & 10 & 6 & 62.38 \\
\hline 18 & 200 & 70 & 10 & 6 & 62.51 \\
\hline
\end{tabular}

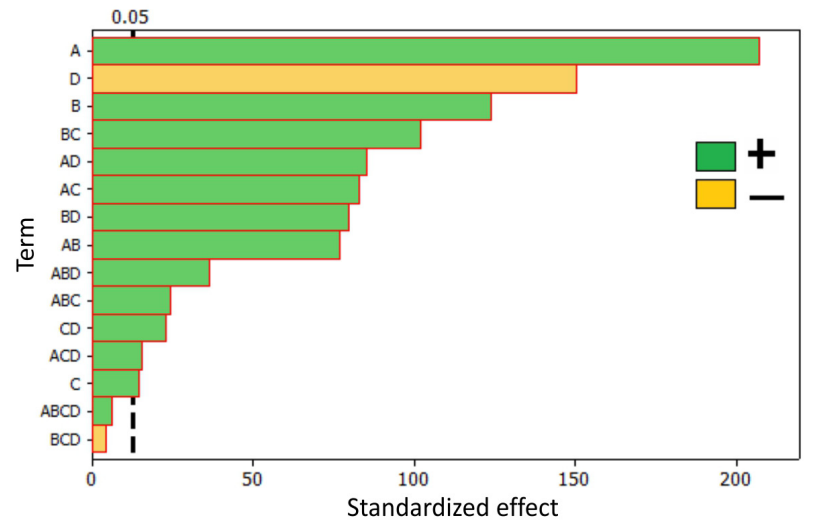

Figure 1. Pareto chart of main effects obtained from $2^{4}$ full factorial designs. The vertical line defines the $95 \%$ confidence interval (A: power, B: temperature, $\mathrm{C}$ : time and $\mathrm{D}$ : volume of nitric acid).

\section{Results and Discussion}

\section{Box-Behnken design}

Factorial design demonstrated that the factors: power, temperature, volume of nitric acid and digestion time in the studied levels need a final optimization.

Therefore, a Box-Behnken experimental design was performed. In this study, the 3-levels, 4-factorial BoxBehnken experimental matrix was used to investigate the parameters that affected the digestion of these element: volume of nitric acid (2-6 mL), power $(300-500 \mathrm{~W})$, extraction time $(16-30 \mathrm{~min})$ and temperature $\left(80-120^{\circ} \mathrm{C}\right)$ were input variables, the factor levels were coded as
-1 (low), 0 (central point) and 1 (high). The design of real experiments is given in Table 2 .

The system behavior can be explained by the following quadratic equation: ${ }^{15}$

$\mathrm{Y}=\beta_{0}+\sum_{i=1}^{k} \beta_{i} \chi_{i}+\sum_{i=1}^{k} \beta_{i i} \chi_{i}^{2}+\sum_{i=1}^{k} \sum_{j=1}^{k} \beta_{i j} \chi_{i} \chi_{j}+\varepsilon$

Here $\mathrm{Y}$ is the process response or output (dependent variable), $k$ is the number of the patterns, $i$ and $j$ are the index numbers for pattern, $\beta_{0}$ is the free or offset term called intercept term, $\chi_{1}, \chi_{2}, \ldots$ and $\chi_{k}$ are the coded independent variables, $\beta_{i}$ is the first-order (linear) main effect, $\beta_{i i}$ is the quadratic (squared) effect, $\beta_{i j}$ is the interaction effect, and $\varepsilon$ is the random error or allows for description or uncertainties between predicted and measured value.

\section{RSM modeling}

In this study, multiple regression analysis was performed with analysis of the RSM for a quadratic response surface model. The response surface analysis allowed the development of an empirical relationship in which the response variable $(\mathrm{Y})$ was assessed as a function of temperature $(\mathrm{T})$, power $(\mathrm{P})$, volume of nitric acid $(\mathrm{V})$ and digestion time (t), four first-order effects (linear term in $T$, $\mathrm{P}, \mathrm{V}$ and $\mathrm{t}$ ), four second-order effects (quadratic terms in $\mathrm{T}^{2}$, $\mathrm{P}^{2}, \mathrm{~V}^{2}$ and $\mathrm{t}^{2}$ ) and six interaction effects (interactive terms in TP, TV, Tt, PV, Pt and Vt). Table 2 shows the matrix and 
Table 2. Design matrix in the Box-Behnken model, observed and predicted values

\begin{tabular}{|c|c|c|c|c|c|c|c|c|}
\hline \multirow{2}{*}{ Trial No. } & \multirow{2}{*}{$\begin{array}{c}\text { Power / } \\
\text { W }\end{array}$} & \multirow{2}{*}{$\begin{array}{c}\text { Temperature / } \\
{ }^{\circ} \mathrm{C} \\
\end{array}$} & \multirow{2}{*}{$\begin{array}{c}\text { time / } \\
\min \end{array}$} & \multirow{2}{*}{$\begin{array}{c}\text { Volume / } \\
\mathrm{mL}\end{array}$} & \multicolumn{2}{|c|}{ Observed, $\mathrm{Y}_{\mathrm{a}}^{\mathrm{a}} /(\mu \mathrm{g}$ per $0.5 \mathrm{~g})$} & \multicolumn{2}{|c|}{ Predicted, $\mathrm{Y}_{\mathrm{p}} /(\mu \mathrm{g}$ per $0.5 \mathrm{~g})$} \\
\hline & & & & & $\mathrm{Zn}$ & $\mathrm{Cu}$ & $\mathrm{Zn}$ & $\mathrm{Cu}$ \\
\hline 1 & 300 & 80 & 23 & 4 & 69.66 & 2.98 & 68.26 & 3.28 \\
\hline 2 & 500 & 80 & 23 & 4 & 75.28 & 3.36 & 75.47 & 3.48 \\
\hline 3 & 300 & 120 & 23 & 4 & 72.47 & 1.94 & 70.61 & 2.34 \\
\hline 4 & 500 & 120 & 23 & 4 & 91.66 & 5.62 & 91.38 & 5.84 \\
\hline 5 & 400 & 100 & 16 & 2 & 71.71 & 4.14 & 68.47 & 4.37 \\
\hline 6 & 400 & 100 & 30 & 2 & 64.85 & 3.98 & 63.08 & 4.15 \\
\hline 7 & 400 & 100 & 16 & 6 & 68.36 & 3.61 & 68.45 & 3.95 \\
\hline 8 & 400 & 100 & 30 & 6 & 70.23 & 4.29 & 71.80 & 4.57 \\
\hline 9 & 300 & 100 & 16 & 4 & 68.65 & 4.31 & 66.56 & 4.12 \\
\hline 10 & 500 & 100 & 16 & 4 & 74.57 & 3.92 & 75.87 & 4.09 \\
\hline 11 & 300 & 100 & 30 & 4 & 62.32 & 2.79 & 60.86 & 2.44 \\
\hline 12 & 500 & 100 & 30 & 4 & 77.58 & 6.15 & 79.52 & 6.17 \\
\hline 13 & 400 & 80 & 23 & 2 & 69.47 & 3.95 & 70.63 & 4.22 \\
\hline 14 & 400 & 120 & 23 & 2 & 71.47 & 3.24 & 72.37 & 3.36 \\
\hline 15 & 400 & 80 & 23 & 6 & 68.64 & 2.94 & 67.59 & 2.65 \\
\hline 16 & 400 & 120 & 23 & 6 & 85.43 & 5.38 & 84.11 & 4.93 \\
\hline 17 & 300 & 100 & 23 & 2 & 65.76 & 1.12 & 69.73 & 0.81 \\
\hline 18 & 500 & 100 & 23 & 2 & 77.62 & 5.92 & 76.60 & 5.43 \\
\hline 19 & 300 & 100 & 23 & 6 & 64.12 & 3.43 & 66.97 & 3.58 \\
\hline 20 & 500 & 100 & 23 & 6 & 90.20 & 2.70 & 88.06 & 2.66 \\
\hline 21 & 400 & 80 & 16 & 4 & 64.48 & 4.86 & 66.09 & 4.56 \\
\hline 22 & 400 & 120 & 16 & 4 & 70.68 & 5.24 & 73.01 & 4.99 \\
\hline 23 & 400 & 80 & 30 & 4 & 63.36 & 4.57 & 62.86 & 4.48 \\
\hline 24 & 400 & 120 & 30 & 4 & 73.97 & 5.51 & 74.19 & 5.47 \\
\hline 25 & 400 & 100 & 23 & 4 & 63.30 & 4.53 & 64.30 & 4.80 \\
\hline 26 & 400 & 100 & 23 & 4 & 65.05 & 4.82 & 64.30 & 4.80 \\
\hline 27 & 400 & 100 & 23 & 4 & 64.56 & 5.06 & 64.30 & 4.80 \\
\hline
\end{tabular}

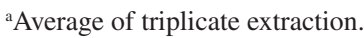

the amount $(\mu \mathrm{g}$ per $\mathrm{g})$ of zinc and copper. The equations below explain the relationship of the four variables that are, $\mathrm{P}, \mathrm{t}, \mathrm{V}, \mathrm{T}$ and $\mathrm{Y}$ (amount of zinc and copper in the samples).

For zinc:

$\mathrm{Y}=459.538-1.3(\mathrm{P})-4.116(\mathrm{~T})-2.353(\mathrm{t})-27.135(\mathrm{~V})+$ $0.001(\mathrm{P})^{2}+0.013(\mathrm{~T})^{2}-0.01(\mathrm{t})^{2}+1.0(\mathrm{~V})^{2}+0.002(\mathrm{~T})(\mathrm{P})+$ $0.003(\mathrm{P})(\mathrm{t})+0.018(\mathrm{P})(\mathrm{V})+0.008(\mathrm{~T})(\mathrm{t})+0.092(\mathrm{~T})(\mathrm{V})+$ $0.156(\mathrm{t})(\mathrm{V})$

For copper:

$\mathrm{Y}=9.05968+0.03(\mathrm{P})-0.16(\mathrm{~T})-0.93634(\mathrm{t})+2.07542(\mathrm{~V})-$ $0.00009(\mathrm{P})^{2}-0.0005(\mathrm{~T})^{2}+0.00554(\mathrm{t})^{2}-0.20302(\mathrm{~V})^{2}+$ $0.00041(\mathrm{~T})(\mathrm{P})+0.00134(\mathrm{P})(\mathrm{t})-0.00691(\mathrm{P})(\mathrm{V})+0.001(\mathrm{~T})(\mathrm{t})+$ $0.01969(\mathrm{~T})(\mathrm{V})+0.015(\mathrm{t})(\mathrm{V})$

The critical points in the surface response model are founded by solving these equations systems for the condition of $\frac{\delta(Y)}{\delta(T)}=0, \frac{\delta(Y)}{\delta(P)}=0, \frac{\delta(Y)}{\delta(V)}=0$ and $\frac{\delta(Y)}{\delta(t)}=0$. The way of calculating these critical points was published in previous study.$^{16}$ The calculated values for the critical point are as follows: temperature of $105.0{ }^{\circ} \mathrm{C}$, irradiation power of $490.0 \mathrm{~W}$, volume of nitric acid of $3 \mathrm{~mL}$ and irradiation time of $20.0 \mathrm{~min}$ for zinc, and temperature of $113.0^{\circ} \mathrm{C}$, irradiation power of $399.0 \mathrm{~W}$, volume of nitric acid of $4.5 \mathrm{~mL}$ and irradiation time of $20.1 \mathrm{~min}$ for copper. The working conditions were established as a compromise between optimum values which were found for each analyte. These values were $110{ }^{\circ} \mathrm{C}, 450 \mathrm{~W}, 4.0 \mathrm{~mL}$ and $21.0 \mathrm{~min}$, for temperature, irradiation power, volume of nitric acid and time, respectively.

The summary of ANOVA is shown in Table 3. According to ANOVA, the $F$-value suggests that most of the differences in the response can be explained using the regression equation. The associated $p$-value is used to estimate whether $F$-value is large enough to show statistical significance. If the $p$-value is lower than 0.05 , it then demonstrates that the model is statistically significant. ${ }^{17}$ The results in Table 3 shows that the regression, linear, interaction and quadratic terms are significant. ANOVA also shows a term for residual error that measures the amount of variation in the response data left unexplained by the model. Analysis shows that the form of the model chosen to explain the relationship between 
Table 3. ANOVA analysis for zinc and copper extractions

\begin{tabular}{|c|c|c|c|c|c|}
\hline Source & Sum of squares & Degree of freedom & Mean of square & $F$-value & $p$-value \\
\hline \multicolumn{6}{|l|}{$\overline{\text { Zinc }}$} \\
\hline Regression & 1500.856 & 14 & 107.204 & 16.5 & $<0.0001$ \\
\hline Linear & 451.86 & 4 & 112.965 & 17.38 & $<0.0001$ \\
\hline Square & 406.766 & 4 & 101.691 & 15.65 & $<0.0001$ \\
\hline Interaction & 196.998 & 6 & 32.833 & 5.05 & 0.008 \\
\hline Residual & 77.988 & 12 & 6.499 & & \\
\hline Lack-of-fit & 76.358 & 10 & 7.636 & 9.37 & 0.1 \\
\hline Pure Error & 1.63 & 2 & 0.815 & & \\
\hline Adjust- $\mathrm{R}^{2}$ & 0.90 & & & & \\
\hline \multicolumn{6}{|l|}{ Copper } \\
\hline Regression & 37.3063 & 14 & 2.66474 & 17.63 & $<0.0001$ \\
\hline Linear & 5.5879 & 4 & 1.39699 & 9.24 & 0.0001 \\
\hline Square & 8.7786 & 4 & 2.19465 & 14.52 & $<0.0001$ \\
\hline Interaction & 16.6188 & 6 & 2.76980 & 18.33 & $<0.0001$ \\
\hline Residual & 1.8136 & 12 & 0.15113 & & \\
\hline Lack-of-fit & 1.6727 & 10 & 0.16727 & 2.37 & 0.333 \\
\hline Pure Error & 0.1409 & 2 & 0.07043 & & \\
\hline Adjust- $\mathrm{R}^{2}$ & 0.90 & & & & \\
\hline
\end{tabular}

the factors and the response is correct. ${ }^{17}$ The non-significant value for lack-of-fit $(>0.05)$ shows that quadratic model is statistically significant for the response.

The three dimensional (Figure 2) response surface plots were used to determine the individual and cumulative effect of the variable and the reciprocal interaction between the variable and the dependent variable. The high $\mathrm{R}^{2}$ values showed that the quadratic equation can represent the system under the given experimental domain.

This is also evident from the fact that the parity plot depicted in Figure 3 indicates a satisfactory correlation between the observed and predicted values of zinc and copper extraction efficiency.

As seen in Figure 3, the fact that the points cluster around the diagonal line shows a good fit of the model since the deviation between the observed and predicted values was less, similarly reported by Yetilmezsoy et al. ${ }^{18}$ The significance of each coefficient was determined by student's $t$-test and $p$-values that are listed in Table 4.

The $p$-value is used as a tool to check the significance of each coefficient. The greater the magnitude of the $t$-value and the lower of the $p$-value, the most significant the factors are in the regression model. ${ }^{18}$ Based on the sum of squares obtained from ANOVA, the percentages of contributions (PC) for each term were calculated and tabulated in Table 4.

$\mathrm{PC}=\frac{S S}{\sum S S} \times 100$

where $S S$ is sum of squares.
The proposed procedure is compared to microwave digestion and FAAS, as recommended for foods in the AOAC Official Methods of Analysis (AOAC 999.11). ${ }^{19}$ The achieved results for proposed method were $180.1 \pm 1.4$ and $5.3 \pm 0.9 \mu \mathrm{g} \mathrm{g}^{-1}$ for zinc and copper, respectively. The achieved results for AOAC method were 181.5 \pm 1.1 and $5.7 \pm 1.0 \mu \mathrm{g} \mathrm{g}^{-1}$ for zinc and copper, respectively.

\section{Analytical application}

The optimized microwave-assisted digestion procedure was applied to the determination of zinc and copper in milk samples. The results obtained are showed in Table 5. Total concentrations of zinc and copper in milk samples were measured by FAAS. Three different milk samples were analyzed. Table 5 presents the total concentration of zinc and copper for 3 milk samples analyzed. $\mathrm{Zn}$ and $\mathrm{Cu}$ were present in all the samples and their concentrations ranged from 100.5 to 182.4 and 3.6 to $5.2 \mu \mathrm{g} \mathrm{g}^{-1}$, respectively.

The accuracy of the method was confirmed by the determination of zinc and copper in the reference sample, namely SRM 8433-Corn Bran from NIST (National Institute of Standards and Technology). The achieved results were $18.47 \pm 1.6$ and $2.43 \pm 0.9 \mu \mathrm{g} \mathrm{g}^{-1}$ for zinc and copper, respectively. The certified values are 18.6 and 2.47 $\mu \mathrm{g} \mathrm{g}^{-1}$ for zinc and copper, respectively. The statistical comparison by $t$-test showed no significant difference between the certificated values and the experimental results. 
(a)
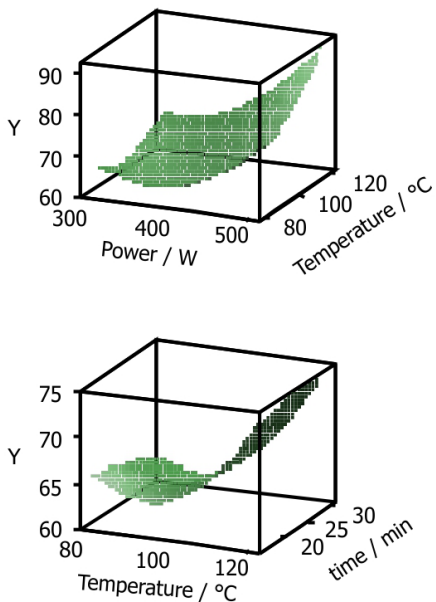

(b)
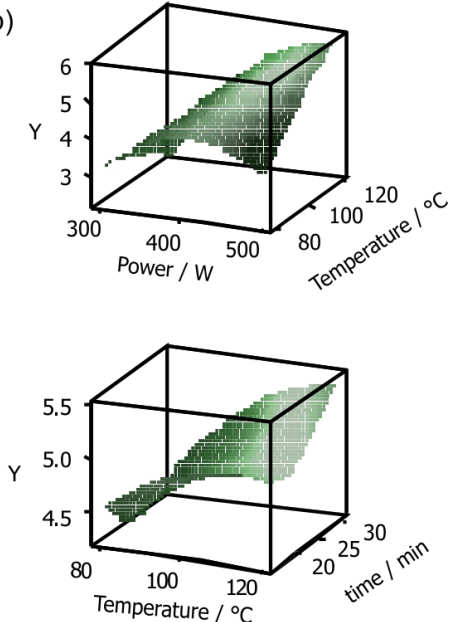
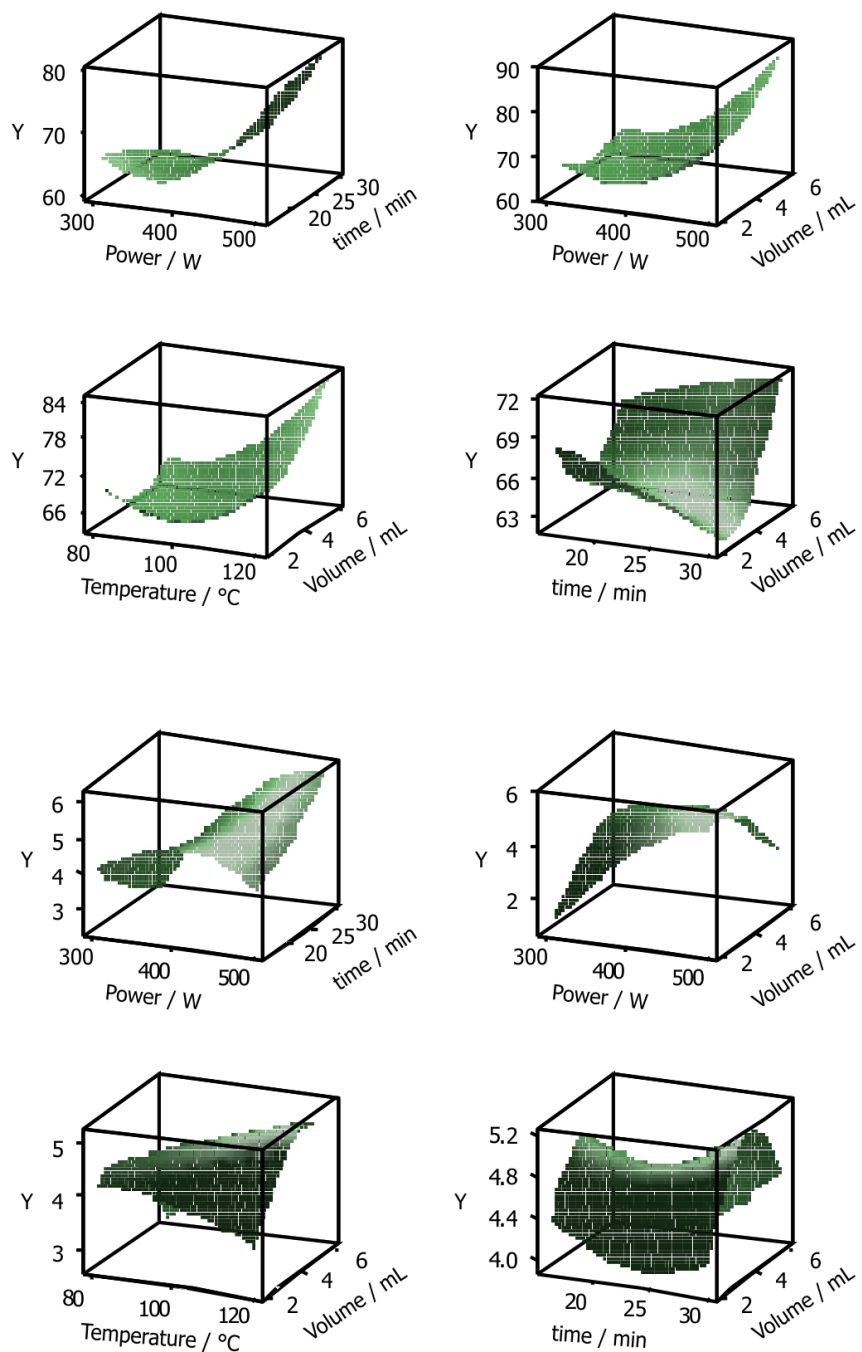

Figure 2. Response surface obtained from Box-Behnken design for extraction efficiency of zinc (a) and copper (b).

Table 4. Multiple regression results and significance of the components for the quadratic model

\begin{tabular}{|c|c|c|c|c|c|c|c|c|c|c|c|}
\hline \multirow{2}{*}{ Factor } & \multirow{2}{*}{ Parameter } & \multicolumn{2}{|c|}{ SE } & \multicolumn{2}{|c|}{$t$-value } & \multicolumn{2}{|c|}{$p$-value } & \multicolumn{2}{|c|}{ SS } & \multicolumn{2}{|c|}{ PC } \\
\hline & & $\mathrm{Zn}$ & $\mathrm{Cu}$ & $\mathrm{Zn}$ & $\mathrm{Cu}$ & $\mathrm{Zn}$ & $\mathrm{Cu}$ & $\mathrm{Zn}$ & $\mathrm{Cu}$ & $\mathrm{Zn}$ & $\mathrm{Cu}$ \\
\hline Intercept & $\beta_{0}$ & & & & & & & & & & \\
\hline $\mathrm{P}$ & $\beta_{1}$ & 0.120 & 0.018 & -6.678 & 1.886 & $<0.0001$ & 0.084 & 289.86 & 0.54 & 21.10 & 1.86 \\
\hline $\mathrm{T}$ & $B_{2}$ & 0.657 & 0.100 & -5.508 & -1.484 & 0.0001 & 0.164 & 197.16 & 0.33 & 14.35 & 1.15 \\
\hline $\mathrm{t}$ & $B_{3}$ & 1.605 & 0.245 & -1.466 & -3.825 & 0.1684 & 0.002 & 13.96 & 2.21 & 1.02 & 7.64 \\
\hline V & $B_{4}$ & 5.104 & 0.778 & -5.317 & 2.667 & 0.0002 & 0.021 & 183.71 & 1.07 & 13.37 & 3.71 \\
\hline $\mathrm{P}^{2}$ & $B_{11}$ & 0.001 & 0.00002 & 6.247 & -5.166 & $<0.0001$ & $<0.001$ & 253.58 & 4.03 & 18.46 & 13.94 \\
\hline $\mathrm{T}^{2}$ & $B_{22}$ & 0.003 & 0.0004 & 4.738 & -1.193 & 0.0005 & 0.256 & 145.91 & 0.22 & 10.62 & 0.74 \\
\hline$t^{2}$ & $B_{33}$ & 0.023 & 0.003 & -0.449 & 1.614 & 0.6613 & 0.133 & 1.31 & 0.39 & 0.10 & 1.36 \\
\hline $\mathrm{V}^{2}$ & $B_{44}$ & 0.276 & 0.042 & 3.752 & -4.824 & 0.0028 & $<0.001$ & 91.48 & 3.52 & 6.66 & 12.15 \\
\hline PT & $B_{12}$ & 0.001 & 0.0001 & 2.662 & 4.244 & 0.0207 & 0.001 & 46.04 & 2.72 & 3.35 & 9.41 \\
\hline $\mathrm{Pt}$ & $B_{13}$ & 0.002 & 0.0003 & 1.832 & 4.823 & 0.0919 & $<0.001$ & 21.81 & 3.52 & 1.59 & 12.15 \\
\hline PV & $B_{14}$ & 0.006 & 0.0009 & 2.789 & -7.112 & 0.0164 & $<0.001$ & 50.55 & 7.65 & 3.68 & 26.43 \\
\hline $\mathrm{Tt}$ & $B_{23}$ & 0.009 & 0.001 & 0.865 & 0.72 & 0.4040 & 0.485 & 4.86 & 0.08 & 0.35 & 0.27 \\
\hline $\mathrm{TV}$ & $B_{24}$ & 0.032 & 0.005 & 2.901 & 4.051 & 0.0133 & 0.002 & 54.69 & 2.48 & 3.98 & 8.57 \\
\hline $\mathrm{tV}$ & $B_{34}$ & 0.091 & 0.014 & 1.712 & 1.08 & 0.1126 & 0.301 & 19.05 & 0.18 & 1.39 & 0.61 \\
\hline
\end{tabular}

SE: Standard error; SS: sum of squares; PC: percentage of contributions; P: power; T: temperature; t: time; V: volume. 

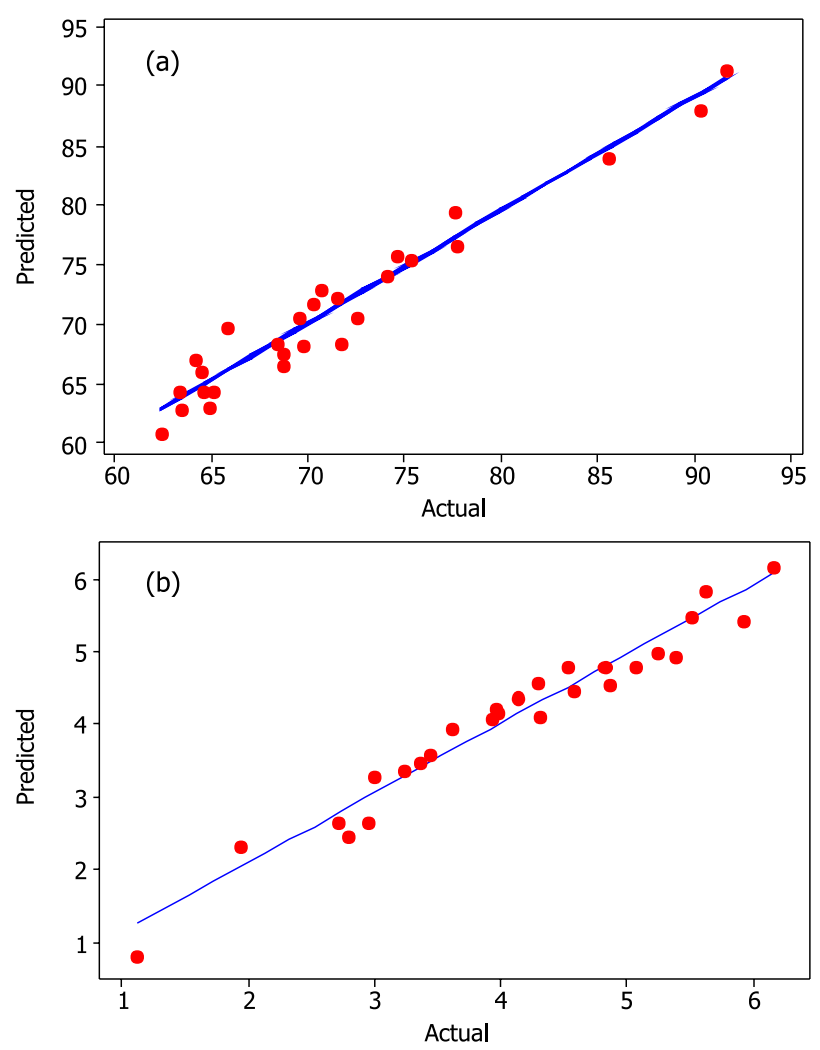

Figure 3. Parity plots show the correlation between the observed and predicted values for zinc (a) and copper (b). Actual and Predicted in $\mu \mathrm{g}$ per $0.5 \mathrm{~g}$.

Table 5. Determination of zinc and copper in the powder milk

\begin{tabular}{lcc}
\hline \multirow{2}{*}{ Sample $^{\mathrm{a}}$} & \multicolumn{2}{c}{ Amount $/\left(\mu \mathrm{g} \mathrm{g} \mathrm{g}^{-1}\right) \pm \mathrm{RSD} / \%$} \\
\cline { 2 - 3 } Humana powder milk 1 & Zinc & Copper \\
\hline Humana powder milk 2 & $182.4 \pm 1.3$ & $5.2 \pm 0.9$ \\
Nan powder milk 1 & $154.5 \pm 1.1$ & $6.9 \pm 1.1$ \\
Nan powder milk 2 & $160.7 \pm 1.5$ & $3.8 \pm 1.2$ \\
Nursoy powder milk 1 & $100.5 \pm 1.0$ & $4.1 \pm 1.0$ \\
Nursoy powder milk 2 & $104.8 \pm 1.2$ & $3.9 \pm 1.4$ \\
\hline
\end{tabular}

aThese samples were selectively purchased from a local market (Zabol, Iran); RSD: relative standard deviation.

\section{Conclusion}

Microwave-assisted digestion method was developed for the fast extraction of zinc and copper from milk. The working conditions were established as a compromise between the optimum values found for copper and zinc. These values were $110{ }^{\circ} \mathrm{C}, 450 \mathrm{~W}, 4.0 \mathrm{~mL}$ and $21.0 \mathrm{~min}$, for temperature, irradiation power, volume of nitric acid and time, respectively. Response surface methodology (RSM) analysis showed good correspondence between observed and predicted values. The application of a Box-Behnken matrix became possible, fast, economical and efficient way of an optimization strategy of the proposed procedure. ${ }^{20,21}$ With respect to other methods proposed for the determination of copper and zinc in milk samples, our method offers the advantages of simplicity and the short time necessary: 21 min versus $5 \mathrm{~h}$ for dry digestion, ${ }^{22}$ and from $>4 \mathrm{~h}$ for wet digestion. ${ }^{23}$

\section{References}

1. Ataro, A.; McCrindle, R. I.; Botha, B. M.; McCrindle, C. M. E.; Ndibewu, P. P.; Food Chem. 2008, 111, 243.

2. Kira, C. S.; Maio, F. D.; J. AOAC Int 2004, 87, 151.

3. Buldini, P. L.; Cavalli, S., Sharma, J. L.; Microchem. J. 2002, $72,277$.

4. Zucchetti, S.; Contarini, G.; At. Spectrosc. 1993, 14, 60.

5. International Dairy Federation; Determination of Zinc Content (Flame Atomic Absorption Method), International IDF, Standard 119, 1992.

6. Association of Official Analytical Chemists (AOAC); Official Methods of Analysis, $16^{\text {th }}$ ed., $4^{\text {th }}$ revision; AOAC International: Gaithersburg, MD, 1998, chapter 9.

7. Kingston, H. M.; Jassie, L. B.; Anal. Chem. 1986, 58, 2534.

8. Oliveira, E.; J. Braz. Chem. Soc. 2003, 14, 174.

9. Lahlali, R.; Massart, S.; Serrhini, M. N.; Jijakli, M. H.; Int. J. Food Microbiol. 2008, 122, 100.

10. Annadurai, G.; Sheja, R. Y.; Bioprocess. Biosyst. Eng. 1998, $18,463$.

11. Huang, Z. L.; Liang, Z. Y., Li, G. J.; Hong, H.; Carbohydr. Polym. 2011, 83, 32.

12. Tiwari, B. K.; Donnell, C. P. O.; Muthukumarappan, K.; Cullen, P. J.; Food Bioprocess Technol. 2009, 2, 109.

13. Borges, K. B.; Pupo, M. T.; de Freitas, L. A. P.; Bonato, P. S.; Electrophoresis 2009, 30, 2874.

14. Turabi, E.; Sumnu, G.; Sahin, S.; Food Bioprocess Technol. 2008, $1,64$.

15. Bayraktar, E.; Process Biochem. 2001, 37, 169.

16. Santos, W. L. D.; Santos, C. M. M. D.; Costa, J. L. O.; Andrade, H. M. C.; Ferreira, S. L. C.; Microchem. J. 2004, 77, 123.

17. Kumar, A.; Prased, B.; Mishra, I. M.; J. Hazard. Mater. 2008, 150, 174.

18. Yetilmezsoy, K.; Demirel, S.; Vanderbei, R. J.; J. Hazard. Mater. 2009, 171, 551.

19. Association of Official Analytical Chemists (AOAC); Official Methods of Analysis, $1^{\text {th }}$ ed., $1^{\text {th }}$ revision; AOAC International: Gaithersburg, MD, 2002, chapter 9.

20. Khajeh, M.; J. Food Comp. Anal. 2009, 22, 343.

21. Khajeh, M.; J. Hazard. Mater. 2009, 172, 385.

22. Fransson, G. B.; LoÈnnerdal, B.; J. Pediatr. 1980, 96, 380.

23. Picciano, M. F.; Guthrie, H. A.; Am. J. Clin. Nutr. 1976, $29,242$.

Submitted: May 17, 2012

Published online: September 11, 2012 